\title{
Hemşirelik Öğrencileri İçin Kimyasal, Biyolojik, Radyolojik, Nükleer Tehlikeler Bilgi, Tutum ve Öz Yeterlilik Ölçeklerinin Geliştirilmesi
}

\section{Assessing Nursing Students' Knowledge Levels, Attitudes, and Self-Efficacy regarding Chemical, Biological, Radiological, and Nuclear Threats and Dangers using Newly Developed Tools}

\section{Derya Aslan Huyar ${ }^{1}$ (D), Melek Nihal Esin² (D)}

İstanbul Üniversitesi- Cerrahpaşa Lisansüstü Eğitim Enstitüsü, İstanbul, Türkiye

2 İstanbul Üniversitesi- Cerrahpașa, Florence Nightingale Hemşirelik Fakültesi İstanbul, Türkiye

ORCID: D.A.H. 0000-0003-2916-7907 M.N.E. 0000-0002-5476-9419

Sorumlu yazar/Corresponding author: Derya Aslan Huyar,

İstanbul Üniversitesi- Cerrahpaşa Lisansüstü Eğitim Enstitüsü, İstanbul, Türkiye

E-posta: deryaslan@uludag.edu.tr

Gelis tarihi/Submitted: 23.10 .2020 İlk revizyon/First Revision Received: 10.11.2020 Son Revizyon/Last Revision Received: 17.11.2020 Kabul Tarihi/Accepted: 15.12 .2020

Atıf/Citation: Aslan Huyar D, Esin MN. Assessing Nursing students' knowledge levels, attitudes, and self-efficacy regarding chemical, biological, radiological, and nuclear threats and dangers using newly developed tools. Sağlık Bilimlerinde İleri Araștırmalar Dergisi 2021; 4(1): 20-30. https://doi.org/10.26650/JARHS2021-815682
ÖZ

Amaç: Hemşirelik öğrencilerinin kimyasal, biyolojik, radyolojik, nükleer (KBRN) tehdit ve tehlikeler hakkında bilgi düzeylerini, tutumlarını ve öz yeterliliklerini belirlemeye yönelik, ölçme araçlarını geliştirmek, geçerlilik ve güvenirliliklerini değerlendirmektir.

Gereç ve Yöntem: Metodolojik tipte planlanmış bir çalışmadır. Basit rastgele örnekleme yöntemi kullanılmıștır. Araștırmaya bir devlet üniversitesinde öğrenim gören 385 hemșirelik bölümü öğrencisi katılmıştır.. Verilerin elde edilmesinde araştırmacı tarafından geliştirilen; "Birey Bilgi Formu”, "Hemşirelik Öğrencisi KBRN Bilgi Testi", "Hemşirelik Öğrencisi KBRN Tutum Ölçeği” ve "Hemşirelik Öğrencisi KBRN Öz Yeterlilik Ölçeği” kullanılmıștır.

Bulgular: Ölçeklerin geçerlik ve güvenirlik testleri için yapılan analizler sonucunda, bilgi testi KR-20 değeri; 0.82 bulunmuștur. Tutum ölçeği 16 maddelik 3 faktörlü yapıdan oluşmaktadır. Faktörler; bireysel tutum, mesleki tutum ve toplumsal tutum olarak adlandırılmıştır. Açıklanan toplam varyans oranı \%66.40’tır. Güvenirlik analizi sonucunda ölçeğin Cronbach's Alfa katsayısı 0.925 olarak hesaplanmıștır. Öz yeterlilik ölçeği, 9 maddeden olușmaktadır. Tek faktörlü yapıda olup açıklanan toplam varyans \%56.240'tır. Cronbach's Alfa katsayısı 0.902 olarak hesaplanmıștır. Bilgi testi, tutum ölçeği ve öz yeterlilik ölçeğinin test tekrar test sonuçlarında anlamlı bir farklılık bulunmamıştır ( $>00,05)$.

Sonuç: Veri toplama araçlarının geçerlilik ve güvenilirliği oldukça yüksek bulunarak, hemșirelik öğrencilerinin KBRN konusunda bilgi, tutum ve öz yeterliliklerini belirlemede yeterli birer ölçme aracı olduğu belirlenmiştir.

Anahtar Kelimeler: Kimyasal savas silahları, biyolojik kontrol ajanları, radyoaktif tehlike salınımı, ölçek geliştirme, hemşirelik öğrencileri

\section{ABSTRACT}

Objective: To develop and evaluate the validity and reliability of the measurement tools in determining the nursing students' knowledge levels, attitudes, and self-efficacy regarding chemical, biological, radiological, and nuclear (CBRN) threats and dangers.

Materials and Methods: This research was methodological; simple random sampling method was used. A total of 385 nursing students studying at a state university participated. The "Individual Information Form," "Nursing Student CBRN Knowledge Test," "Nursing Student CBRN Attitude Scale," and "Nursing Student CBRN Self-Efficacy Scales," which were developed by the researcher, were used for obtaining data.

Results: The analyses performed for assessing the validity and reliability of the scales revealed the KR-20 value of the knowledge test to be 0.82 . The Nursing Student CBRN Attitude Scale consisted of a 3-factor structure with 16 items. The three factors include individual, professional, and social attitudes. The total variance ratio explained by the scale was $66.40 \%$. The Cronbach's alpha coefficient of the scale was 0.925 . The self-efficacy scale consisted of a single-factor structure including nine items. The total variance ratio explained by the scale was $56.24 \%$. The Cronbach's alpha coefficient of the scale was 0.902 . No significant difference was found in the test-retest results of the Nursing Student CBRN Knowledge Test, Nursing Student CBRN Attitude Scale, and Nursing Student CBRN Self-Efficacy Scales ( $\mathrm{p}>0.05$ ).

Conclusion: The validity and reliability of the data collection tools were found to be quite high, and it was determined that they were efficient measurement tools to determine the knowledge, attitude, and self-efficacy of nursing students regarding CBRN threats and dangers.

Keywords: Attitude, chemical, biological, radiological, and nuclear threats and dangers, knowledge, nursing students, self-efficacy 


\section{GíRIŞ}

KBRN tehdit ve tehlikeleri kavramı; kimyasal, biyolojik, radyolojik ve nükleer terimlerinin kısaltmasıdır. Bu maddelerin kazaen veya kasten yayılımıyla oluşan, insan ve çevre sağlı̆̆ i için zararlı olan durumları ifade etmektedir (1). Kimyasal tehlikeler; kimyasal savaş ajanları, zararlı endüstriyel veya ev kimyasalları dahil olmak üzere kimyasal maddelerin neden olduğu zehirlenme veya yaralanmaları kapsar. Biyolojik tehlikeler; tehlikeli bakteri, virüs veya toksinlerin kasıtlı salınımının neden olduğu hastalıkları, radyolojik tehlikeler; zararlı radyoaktif maddelere maruz kalmanın neden olduğu hastalıkları içerir. Nükleer tehlikeler ise; nükleer bir patlamadan kaynaklanan nükleer radyasyona, termal etkiye, $1 s ̧ 1 \mathrm{k}$ etkisine ve basınç etkisine maruz kalmanın neden olduğu hayatı tehdit eden sağlık sorunlarını ifade etmektedir (2). Sağlık sorunları bağlamında; KBRN ajanlarına maruz kalmış kişilere uygun ve zamanında acil müdahale yapılması oldukça önemlidir. Hemşirelerin bu tür bir halk sağlığg tehditliyle mücadele edebilmeleri için; temel olarak KBRN'ye giriş, triyaj, müdahale prosedürleri, dekontaminasyon prosedürleri, olay yeri yönetimi, psikososyal etkilerin yönetimi, sürveyans, iletişim, olayı rapor etme, karantina uygulamalarını gerçekleştirme ve majör halk sağlı̆̆ acillerine liderlik etme gibi yeterliliklere sahip olmaları gerekir $(3,4)$. Hemşirelere biyolojik ve kimyasal acil durumlarla ilgili eğitimler verilmesi ve en az bir dizi klinik yeterliliğin sağlanması gereklidir (3). Amerikan Hemşirelik Yüksek Okulları Birliği’nin (AACN) 2001 yılındaki basın açıklamasına göre; “Tüm hemşireler temel eğitiminin bir parçası olarak nükleer biyolojik ve kimyasal acil durumlara cevap vermek için eğitim almalıdır”. Ayrıca Devlet Sağlık Departmanları ve Sağlık Kurumları Akreditasyon Ortak Komisyonu/Joint Commission on Accreditation of Healthcare Organizations (JCAHO), hemşirelerin felaket hazırlıkları ve tehlikeli maddelerin dekontaminasyonu konusunda bilgi ve beceri sahibi olması gerektiğini vurgulamıştır $(5,6)$. Bu konuya ait bilgi ve beceri eksikliğini gösteren en iyi örneklerden biri Tokyo metrosunda gerçekleştirilen sarin gazı saldırısıdır. Bu saldırıda 12 kişi ölmüş, 6.000'den fazla insan zehirlenmiş ve 472 hastane çalışanın 100'den fazlası müdahale sırasında gazdan etkilenmiștir. Etkilenen sağlık personeli sayısının bu denli yüksek oluşunun nedenleri arasında; yeterli kişisel koruyucu ekipman bulunmaması, dekontaminasyon işlemlerinin hatalı ve eksik yapılmasının yanı sıra iletişim ve organizasyon eksikliği olduğu belirlenmiştir (7). Sarıtaş ve arkadaşları tarafından yapılan "Acil Servis Hemşirelerinin Biyoterörizm Konusundaki Bilgi ve Görüşleri” hakkındaki çalışmada hemşireler; eğitim ihtiyaçları olduğunu, ülkemizin riskli bir konumda olduğunu ve özellikle acil servis çalışanlarının bu tür tehlikelerde rol ve sorumlulukları olduğunu belirtmişlerdir (8). Bu bağlamda ülkemizde hemşirelik çerçevesinde, KBRN konusundaki eksikliklerin daha ayrıntılı bir biçimde ortaya konması ve çözüm yollarının oluşturulabilmesi için; bilgi, tutum ve öz yeterlilik düzeylerini tanımlamamızı, anlamlandırılabilmemizi sağlayan ölçüm araçlarına gereklilik olduğu düşünülmüştür.

Bu bağlamda, araştırmada hemşirelik öğrencilerinin kimyasal, biyolojik, radyolojik, nükleer (KBRN) tehdit ve tehlikelere yönelik bilgi düzeyleri ile tutum ve öz yeterlilik algılarını belirlemeye yönelik ölçme araçlarını geliştirmek amaçlanmış olup bu çalışmanın konu ile ilgili literatüre katkı sağlayacağı ve alanda çalıșan araștırmacılara kullanabilecekleri ölçüm araçları sağlayacağı düşünülmektedir.

\section{GEREÇ VE YÖNTEM}

Araştırma tipi: Bu çalışma geçerlik ve güvenirlik çalışmalarının yapılması nedeniyle metodolojik bir çalışmadır.

Araştırmanın yapıldığı yeri ve zamanı: Bir devlet üniversitesinde öğrenim gören hemşirelik öğrencileri ile Nisan-Haziran 2019 tarihleri arasında yürütülmüştür.

Araştırmanın evren ve örneklemi: Araştırmanın evrenini, bir devlet üniversitesinde öğrenim gören 770 hemşirelik bölümü öğrencisi oluşturmaktadır. Örneklem sayısı hesaplanırken beklenen Tip 1 hata $\% 5$, güven aralığı $\% 99$ olarak alınmıştır. Örneklem büyüklügü 356 kişi olarak hesaplanmış olup, yanıtsızlık oranın tahmini \%10 olması halinde örneklem sayısı 395 kişi 
olarak belirlenmiștir. Öğrencilerin sınıf listeleri alınarak kişilere sıra numarası verişmiştir ve bu listeden 395 kişi basit rastgale örnekleme yöntemi kullanılarak seçilmiştir. Formları eksiksiz dolduran 385 kişi değerlendirmeye dahil edilmiştir. Örnekleme dahil edilmeyen 30 öğrenci ile pilot uygulama, 89 öğrenci ile de test tekrar test analizi yapılmıştır.

Veri toplama araçları: Ölçek maddelerinin geliştirilmesi sürecinde; Büyüköztürk, Kılıç Çakmak, Akgün, Karadeniz ve Demirel tarafından açıklanan aşamalar takip edilmiştir (9).

1. Aşama- Problemi tanımlama: Binlerce kimyasal, radyolojik ve nükleer çalışma alanını barındıran ülkemiz ve dünyamız her gün yüzlerce çeşitli kaza riskini barındırmaktadır. Milattan öncesinden günümüze değin çok sayıda KBRN kazası ve saldırısı gerçekleşmiş olup, bu durum birçok insanın yaşamını kaybetmesine, sağlı̆̆ından olmasına ve ülkelerin ciddi ekonomik kayıplar yaşamasına neden olmuştur. 1.Dünya Savaşı esnasında Fosgen, Klor, Siyanür ve Hardal gibi farklı kimyasal savaş ajanları kullanılarak yaklaşı 90.000 kişi öldürülmüştür. Japonya biyolojik ajanları (tifo, kolera ve veba) kullanarak salgınlar oluşturmuş, on binlerce insanın ölümüne yol açmıştır. Hiroşima ve Nagasaki'ye firlatılan atom bombaları 250.000'den fazla insanın ölümüne ve milyonlarca kişinin çeşitli biçimlerde etkilenmesine yol açmıştır (10). Ayrıca dünyamız şuan bir virüsün yarattığ ${ }_{1}$ Covid-19 pandemisini deneyimlemektedir. Tüm bu yaşanan olayların sonucunda akut veya kronik sağlık hizmeti ihtiyacı doğmaktadır. Giriş bölümünde sözü edilen çalışmaların sonuçlarına göre katılımcı hemşirelerin çoğunda KBRN tehdit ve tehlikelerine yönelik bilgi, tutum ve beceri eksiklikleri bulunmaktadır. Bu bağlamda hemşire adaylarının KBRN tehdit ve tehlikelere yönelik bilgi düzeyleri ile tutum ve öz yeterlilik algılarını belirlemeye ihtiyaç duyulmaktadır.

2. Aşama- Madde yazma: Değerlendirilmek istenen kavramların farklılıkları sebebiyle veri toplama formları; bilgi, tutum ve öz yeterlilik olarak 3 ayrı başlık altında planlanmıştır. Bu öğeler Bloom’un taksonomisinde önerdiği; bilişsel, duyuşsal ve devinimsel öğrenme alanları ile örtüşmektedir. Ölçek geliş- tirme sürecinde araştırma teknikleri bakımından uyulması gereken aşamalar izlenirken, madde havuzunun yazılması aşamasında Bloom taksonomisinden yararlanılmıştır. Madde havuzu literatür taramasıyla oluşturulmuştur $(3,4,8,11-24)$. Yazılan maddeler dil ve anlam bilgisi yönünden incelenmiş ayrıca açık, anlaşılır olma ve biçim özellikleri açısından araştırmacılar tarafından gözden geçirilmiştir. Bu aşamada bazı yazım hataları ve anlam bozukluğu olan maddeler düzeltilmiş, madde sıralamalarında değişiklikler yapılmıştır. Taslak bilgi testi ve tutum ölçeği 36'şar maddeden, öz yeterlilik ölçeği 9 maddeden oluşturulmuştur. Düzenlenen bu formlar uzmanlara gönderilmeden önce toplam 30 öğrenciye ayrı ayrı sunulmuştur. Öğrencilerin görüşleri doğrultusunda anlaşılmayan terimler ve ifadeler sadeleştirilmiştir.

3. Aşama- Uzman görüşü alma ve ön uygulama formu oluşturma: Uzman görüşü almak amaciyla üç form için ayrı ayrı "Uzman Değerlendirme Formu" oluşturulmuştur. Bu formda uzmanlara çalışmanın amacı açıklanarak uzmanların maddelere yönelik objektif görüşleri talep edilmiştir. Uzmanlardan her madde için görüşlerini Lawshe tarafından geliştirilen teknik kullanılarak "Uygun”, "Uygun ancak düzeltilmeli", "Çıkartılmalı" seçeneklerini işaretleyerek belirtmeleri istenmiştir. Formlar 8 uzmana gönderilmiştir (25). Bu uzmanlar KBRN konusunda çalışmalar yapmış akademisyenler, UMKE ve AFAD’ta çalışan KBRN uzmanları ile ölçek geliştirme konusunda deneyimli uzman kişilerden oluşmaktadır. Gelen sonuçlar doğrultusunda kapsam geçerlik oranları hesaplanarak, kapsam geçerlik indeksleri belirlenmiştir. "Lawshe Minimum İçerik Geçerliliği Oranları (İG) " kapsamında 8 uzman için verilen değer, 0.78'dir (26). 0.78'den küçük çıkan maddeler soru havuzundan çıkartılmıştır. Revize edilmesi not edilen ifadeler yeniden düzenlenmiștir. Bunun neticesinde bilgi testinde, 36 ifadeden 5 madde; tutum ölçeğinde 36 maddeden 16 madde çıkartılmıştır. Öz yeterlilik ifadelerinden ise uzman görüş sonrası madde elenmesine gerek kalmamıştır. Taslak ölçeklerin Kapsam Geçerlilik İndeksi (KGİ=Content Validity Index=CVI) \%78 bulunmuş olup veri toplama formlarının kapsam geçerliğinin iyi düzeyde olduğu belirtilebilir. 
4. Aşama - Ön uygulama, analizler ve veri toplama formuna son şeklini verme: 385 form analiz edilmiştir. Bilgi testi cevap seçenekleri doğru ve yanlıs ifadelerinden oluşmaktadır. Tutum ve öz yeterlilik ölçekleri ise “5” tamamen katılıyorum ile "1" kesinlikle katılmıyorum arasında değerlendirilen Likert tipte ölçeklerdir. Ölçeklerin kendi içinde alınan puanları arttıkça öğrencilerin KBRN bilgi, tutum ve öz yeterlilik düzeyleri de olumlu yönde artmaktadır. Ayrıca öğrencilere ait demografik verileri almak için 9 maddeden oluşan bir birey bilgi formu da kullanılmıştır.

İstatistiksel analizler: Verilerin analizi için IBM SPSS Statistics 25 istatistik programı kullanılmıştır. Ölçeklerin geçerlilik ve güvenilirlik çalışmaları kapsamında; Kapsam Geçerlilik İndeksi ve Lawshe’nin Kapsam Geçerliliği Oranı (KGO) kullanılmıştır (25). Ayrıca Cronbach Alpha, Pearson Korelasyon ve Faktör analizi testleri olarak; KMO, Bartlett Testi, Temel Bileşenler Analizi ve Varimax Döndürme Yöntemi uygulanarak elde edilmiştir (39).

Araştırmanın etik yönü: Bursa Uludağ Üniversitesi Araştırma ve Yayın Etik Kurulları-Sağlık Bilimleri Araştırma ve Yayın Etik Kurulu'ndan 27 Mart 2019 tarihinde Karar No:10’da belirtildiği üzere etik kurul onayı alınmıştır. Bilgilendirilmiş Gönüllü Onam Formları alındı.

\section{BULGULAR}

\section{Katılımcıların özellikleri}

Katılımcıların \%84.5’i kadın, \%15.5'i erkek öğrencilerden oluşmaktadır. GANO (Genel Akademik Not Ortalaması) aralıklarına bakıldığında; GANO’su 1.51-2.00 arasında 7 kişi, \% 1.8 oranla, 2.01-2.5 olanlar \%11.1 oranla 36 kişi, 2.51-3.00 olanlar \%53.9 oranla 165 kişi, 3.01 ve üzerinde ortalaması olanlar ise \%46.1 oranla 178 kişi yer almaktadır. Katılımcıların yaş ortalaması; 21.49 olup minimum 20 maksimum 29 yaş olduğu görülmektedir. Mesleki eğitiminiz sırasında KBRN'ye yönelik herhangi bir eğitim aldınız mı? Sorusuna \%94 oranla 363 kişi "hayır" cevabı vermiştir. "Evet" yanıtı verenlerin formları incelendiğinde bu öğrencilerin hastanede çalışan öğrenciler olduğu ve eğitimi kurum içi eğitimler ile aldıkları öğrenilmiştir. KBRN’ye yönelik eğitim almak ister misiniz? sorusuna $\% 83.9$ oranla 324 kişi "hayır" cevabı vermiştir. KBRN olgularına müdahale edebilmenin mesleğiniz için gerekli olduğunu düşünüyor musunuz? sorusuna \%91.7 oranla 354 kişi "hayır", \%8.3 oranla 32 kişi "evet" cevabı vermiştir.

\section{Güvenirlik ve Geçerlilik Çalışmasına İlişkin Bulgular}

Ölçeğin öncelikli olarak yüzey ve kapsam geçerliliği test edilmiştir. Yüzey geçerliliğini sağlamak için taslak ölçek literatür destekli geliştirilmiştir. Yazılan maddelerin çalışmanın amacına uygun, hedef grubun bilgi ve eğitim düzeyini zorlamayan, okunaklı ve anlaşılır olmasına özen gösterilmiştir. Ardından 30 hemşirelik öğrencisi üzerinde ön deneme uygulaması gerçekleștirilmiştir.

Kapsam geçerliliğini sağlamak için 8 uzmandan "Uzman Değerlendirme Formu" aracıllı̆̆ ile görüşleri alınmıştır. Kapsam Geçerlilik İndeksi (KGİ=Content Validity Index=CVI); \%78 bulunmuştur.

Madde analizi: Tutum Ölçeğindeki madde-toplam korelasyon değerlerinin ilk hesaplamada 0.30 'un altında kalan 1, 2, 3 ve 12 numaralı maddeler çıartılmıştır. Çıkartılan maddeler sonrasında tekrar edilen analiz sonucunda tutum ölçeğindeki madde-toplam korelasyon değerlerinin. $r=0.33$ ile 0.77 arasında olduğu, pozitif yönde ve istatistiksel olarak anlamlı düzeyde olduğu bulunmuştur. Öz yeterlilik ölçeğinin madde toplam korelasyon değerlerinin $\mathrm{r}=0.59$ ile 0.81 arasında olduğu ve bu değerlerinin istatistiksel olarak anlamlı olduğu görülmüştür. 0.30’un altında kalan bir madde olmadığı için herhangi bir madde çıkartılmamıştır.

Bilgi testi için; Madde Güçlügü ve Madde Ayırıc1lık Gücü hesaplanmıştır. Maddeler "Madde Güçlük ve Ayırt Edicilik için değerlendirme kriterleri” doğrultusunda değerlendirilmiş olup, aynı anda $\mathrm{p}<0.60, \mathrm{r}>0.20$ çıan herhangi bir madde olmadığı için bilgi testinden herhangi bir madde çıkartılmamıştır (26).

Ölçeklerin faktör yapısı: Tutum ve öz yeterlilik ölçeklerinin yapı geçerliliğinin belirlenmesi için açımlayıcı faktör analizi yapılmıştır. Yapılan Barlett Testi sonucunda $(\mathrm{p}=0.000<0.05)$ faktör analizinde yer alan değişkenler arasında her iki ölçek içinde ilişkinin var olduğu tespit edilmiştir. Yapılan KMO 
Tablo 1. Hemşirelik öğrencisi KBRN tutum ölçeği ve hemşirelik öğrencisi KBRN öz yeterlilik ölçeği faktör yapısı. Tutum ölçeği faktör yapıs Faktör yükü

Mesleki tutum (Özdeğer=7.646; Açıllanan varyans=28.108; Alpha=0.896)

19. Herhangi bir KBRN tehdidi olduğunda çalıştığım çalışacağım kurumun afet ve acil durum planında etkin rol almakta gönüllü olurum

17. Hemşirelik mesleğimi icra ederken biyolojik bir savaş ajanı ile karşılaşma ihtimalimin diğer sağlık dışı meslek gruplarına göre daha olası olduğunu düşünürüm

13. Halkımıza kimyasal biyolojik, radyolojik ve nükleer olaylara karşı nasıl hazırlıklı olacaklarına dair bilgi vermek isterim

20. KBRN (kimyasal biyolojik, radyolojik ve nükleer) konusuna hemşirelik lisans eğitimimde yer verilmesinin gerekli olduğunu düşünüyorum

14. KBRN (kimyasal biyolojik, radyolojik ve nükleer) tehdit ve tehlikeleri kapsamında bilgi sahibi olmam mesleki açıdan önceliklerim arasındadır

15. Kimyasal biyolojik, radyolojik ve nükleer durumlarla ilgili bir makale gördüğümde okurum

16. Kimyasal biyolojik, radyolojik ve nükleer bir konuya dair makale gördüğümde meslektaşlarımla paylaşırım

18. Kimyasal biyolojik, radyolojik ve nükleer tehdit ve tehlikeler konusunda hemşireler meslek içi eğitimler düzenlemelidir

Bireysel tutum (Özdeğer=1.694; Açılanan varyans=20.268; Alpha=0.875)

4. KBRN (kimyasal biyolojik, radyolojik ve nükleer) farkındalık eğitimi için vakit ayırmak önceliklerim arasindadir

5. Kimyasal, biyolojik, radyolojik ve nükleer tehdit ve tehlikelere yönelik ücretsiz bir farkındalık eğitim etkinliği planlanırsa katılmak isterim

6. KBRN (kimyasal biyolojik, radyolojik ve nükleer) tehdit ve tehlikelerine yönelik bilgilendirme afişi gördügümde durup bu afişi okurum

7. KBRN (kimyasal biyolojik, radyolojik ve nükleer) ikaz alarm ve işaretlerini bilmem gerektiğine inanırım

Toplumsal tutum (Özdeğer=1.285; Açıklanan varyans=18.025; Alpha=0.805)

8. KBRN (kimyasal biyolojik, radyolojik ve nükleer) olaylarında ikincil kirlenme açısından riskli grupta yer alan meslek grupları arasında sağlık çalışanlarının da olduğunu düşünüyorum

9. Hasta yaralı müdahalesi esnasında kişisel koruyucu donanım kullanmanın gerekliliğine inanıyorum

11. Radyasyondan korunmak için neler yapılması gerektiğini tavsiye eden kamu bilgilendirme spotları oluşturulması gerektiğine inanıyorum

10. KBRN (kimyasal biyolojik, radyolojik ve nükleer) tehdit ve tehlikelerine karşı toplumsal olarak

hazırlık olmak gerektiğine inanıyorum

0.634

0.628

0.62

0.617

0.592

Toplam varyans $=\% 66.401$; Genel güvenirlik $($ Alpha $)=0.925$

Öz yeterlilik ölçeği faktör yapısı

2. KBRN mağduru hastaya müdahale etmeden önce giymem gereken KBRN olgularına özgü geliştirilmiş kişisel koruyucu donanım düzeylerini tanırım

8. Kimyasal biyolojik, radyolojik ve nükleer kaynaklı bir olay meydana geldiğinde Rinse-Wipe-Rinse metodunu kullanarak doğru bir dekontaminasyon yaparım

3. Kimyasal, biyolojik, radyolojik ve nükleer olgularında kişisel koruyucu donanımı doğru şekilde giyerim

5. Kimyasal ajan tespitinden sonra gerekliyse hastaya göz duşu/ irigasyonu uygulamasını yaparım

9. Kimyasal gazdan kontamine olmuş kıyafetlerimi doğru şekilde çıkartıp, izole ederim

7. Eğer standart kişisel koruyucu önlemler almam gereken bir vaka varsa bu standart kişisel koruyucu önlemleri uygulayabilirim

1. Kimyasal, biyolojik, radyolojik ve nükleer tehditleri anlamam ve önlem alam için gerekli olan İkaz alarm ve işaretlerinin tüm renk ve seslerini tanırım

6. Kimyasal biyolojik, radyolojik ve nükleer kaynaklı bir olay meydana geldiğinde görevlendirildiğim alanda Kitlesel Triyaj yaparım

4. Kimyasal, biyolojik, radyolojik ve nükleer olgularında gaz maskemi doğru şekilde takarım

Özdeğer=5.062; Toplam varyans $=\% 56.240 ;$ Genel güvenirlik $($ Alpha $)=0.902$ 
testi sonucunda tutum ölçeği $\mathrm{KMO}=0.893>0.60$; öz yeterlilik ölçeği $\mathrm{KMO}=0.910>0.60$ örneklem büyüklüğünün faktör analizi uygulanması için uygun yeterlilikte olduğu tespit edilmiştir. Faktör analizinin yapılmasında varimax yöntemi seçilerek faktörler arasında bulunan ilişki yapısının aynı şekilde kalması sağlanmıştır. Bu faktör analizi sonucunda tutum ölçeğinde, değişkenler toplam açılanan varyansı \%66.401 olan 3 faktör altında toplanmıştır. Bu üç faktörün varyans katkı oranları sırasıyla; 28.10, 20.26, 18.02'dir. Her faktör, öğelerinin içeriğine göre özetlenmiş ve isimlendirilmiştir: Mesleki Tutum (Faktör 1), Bireysel Tutum (Faktör 2), Toplumsal Tutum (Faktör 3) olarak adlandırılmıştır. Öz yeterlilik ölçeği faktör analizi sonucuna göre toplam açıklanan varyans \%56.240’tır ve tek faktör altında toplanmıştır. Tutum ve öz yeterlilik ölçeklerine ait faktör yapısı Tablo 1'de görülmektedir.

Tablo 2. Hemşirelik öğrencisi KBRN bilgi testi güvenirlik analizleri.

\begin{tabular}{|l|c|}
\hline Güvenirlik katsayıları & Değer \\
\hline Cronbach's Alpha & 0.823 \\
\hline Split-Half (odd-even) Correlation & 0.734 \\
\hline Spearman-Brown Prophecy & 0.846 \\
\hline Mean for Test & 10.183 \\
\hline Standard Deviation for Test & 5.162 \\
\hline KR21 & 0.768 \\
\hline KR20 & 0.823 \\
\hline
\end{tabular}

Ölçeklerin Güvenirliği: Bilgi Testi için KR-20 değeri; 0.82 olarak hesaplanmıştır (Tablo 2). Tutum ölçeği Alpha katsayısı 0.925; öz yeterlilik ölçeği Alpha katsayısı 0.902 olarak bulunmuştur. Güvenirliğine ilişkin elde edilen alpha ve açılanan varyans değerine göre “Hemşirelik Öğrencisi KBRN Tutum Ölçeği”nin ve "Hemşirelik Öğrencisi KBRN Öz Yeterlilik Ölçeği"nin geçerli ve güvenilir birer araç olduğu anlaşılmıştır.

Test Tekrar Test Güvenirliği: 2 hafta sonrasında ölçümler 89 kişi üzerinde tekrarlanmıştır. Tablo 3’te görüldüğü gibi; KBRN bilgi puanları, mesleki tutum, bireysel tutum, toplumsal tutum, tutum ölçeği genel puanları ile öz yeterlilik puanları test-tekrar değişkenine göre istenen şekilde anlamlı bir farklılık göstermemektedir $(\mathrm{p}>0.05)$.

\section{TARTIŞMA}

Ölçekler geliştirilmeye çalışılırken öncelikli olarak literatür taraması yapılmıștır. Çalışmalar incelendiğinde genel olarak hastane çalışanları, Acil Tip çalışanları, KBRN olaylarında ilk müdahale ekipleri ile Acil Yardım ve Afet Yönetimi Bölümü öğrencilerinin ele alındığ görülmüştür. Hemşireler bağlamında ise biyoterörizm ve kimyasal ajanlar konusundaki bilgi düzeylerinin ele alındığ çalışmalara erişilmiştir $(8,13,28-34)$. Literatür taraması neticesinde; ülkemizde hemșireler veya hemșire adaylarının KBRN tehdit ve tehlikelerine yönelik bilgi, tutum ve öz ye-

Tablo 3. Hemşirelik öğrencisi KBRN bilgi testi, hemşirelik öğrencisi KBRN tutum ölçeği ve hemşirelik öğrencisi KBRN öz yeterlilik ölçeği test tekrar test sonuçları.

\begin{tabular}{|c|c|c|c|c|c|c|c|c|}
\hline \multicolumn{2}{|c|}{ Veri toplama araçları } & Grup & $\mathbf{N}$ & Ort & Ss & $t$ & sd & p \\
\hline \multicolumn{2}{|c|}{ KBRN bilgi testi } & Test & 89 & 10.933 & 5.364 & -0.198 & 176 & 0.843 \\
\hline \multirow{8}{*}{ 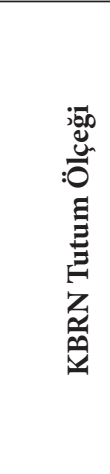 } & \multirow[b]{2}{*}{ Mesleki tutum } & Test & 89 & 3.799 & 0.757 & \multirow[b]{2}{*}{-0.53} & \multirow[b]{2}{*}{176} & \multirow[b]{2}{*}{0.597} \\
\hline & & $\begin{array}{c}\text { Tekrar } \\
\text { test }\end{array}$ & 89 & 3.855 & 0.653 & & & \\
\hline & \multirow[b]{2}{*}{ Bireysel tutum } & Test & 89 & 3.983 & 0.825 & \multirow[b]{2}{*}{0.561} & \multirow[b]{2}{*}{176} & \multirow[b]{2}{*}{0.576} \\
\hline & & $\begin{array}{c}\text { Tekrar } \\
\text { test }\end{array}$ & 89 & 3.913 & 0.846 & & & \\
\hline & \multirow[b]{2}{*}{ Toplumsal tutum } & Test & 89 & 4.264 & 0.793 & \multirow[b]{2}{*}{-0.312} & \multirow[b]{2}{*}{176} & \multirow[b]{2}{*}{0.755} \\
\hline & & $\begin{array}{c}\text { Tekrar } \\
\text { test }\end{array}$ & 89 & 4.301 & 0.768 & & & \\
\hline & \multirow[b]{2}{*}{$\begin{array}{l}\text { KBRN Tutum } \\
\text { Ölçeği genel }\end{array}$} & Test & 89 & 3.961 & 0.659 & \multirow[b]{2}{*}{-0.325} & \multirow[b]{2}{*}{176} & \multirow[b]{2}{*}{0.745} \\
\hline & & $\begin{array}{c}\text { Tekrar } \\
\text { test }\end{array}$ & 89 & 3.992 & 0.607 & & & \\
\hline \multirow{2}{*}{\multicolumn{2}{|c|}{ KBRN Öz Yeterlilik }} & Test & 89 & 27.337 & 6.966 & \multirow[b]{2}{*}{0.601} & \multirow[b]{2}{*}{176} & \multirow[b]{2}{*}{0.548} \\
\hline & & $\begin{array}{c}\text { Tekrar } \\
\text { test }\end{array}$ & 89 & 26.663 & 7.96 & & & \\
\hline
\end{tabular}


terliliklerini belirlemeye yönelik geçerlilik ve güvenilirlik çalışmaları yapılmış bir ölçme aracının yok denecek kadar az olduğu görülmüştür.

Ülkemizde yapılan bir çalışmada hemşirelerin; \%65’i kimyasal saldırılara yönelik herhangi bir eğitim görmediklerini, \%78.5’inin bu hususlarda eğitim almak istediklerini belirttikleri ayrıca toplumu bilinçlendirmek eğitmek noktasında hemşirelerin \%69.6'sının aktif rol almaları gerektiğini inandıkları ve bu grubun yaklaşık yarsının eğitim vermeye gönüllü olduklarını belirttiği görülmektedir. Hemşirelerin büyük bir çoğunluğunun kimyasal saldırı durumunda yapılması gerekenlere yönelik sorulara "bilmiyorum" yanıtı verdiği saptanmıştır. Acil servis hemşireleri ile yürütülen ve biyoterörizm konusundaki bilgileri ile görüşlerini sorgulayan başka bir çalışmada hemşirelerin \%57.8'inin biyoterörizm kavramını bildiği fakat daha yoğun bir eğitim almak istedikleri ve ülkemizi riskli konumda gördüklerini ortaya konmuştur $(8,33)$. Konu ve örneklem grubu benzerliği göz önüne alınarak yurt dışındaki çalışmalar incelendiğinde, gerek tüm sağlık çalışanları gerek yalnız hemşirelerin, KBRN tehditlerine yönelik bilgi düzeylerini, tutumlarını değerlendiren bunun yanında girişimsel çalışmaların sonuçlarını ölçebilmek için ölçekler ve farklı çeşitte soru formları ile eğitim materyallerinin geliştirildiği görülmektedir $(4,11,12,18-24)$.

Ülkemizde ve yurtdışında yapılan çalışmaların çoğunda hemşirelerin KBRN tehdit ve tehlikelerine yönelik yapılması gerekenler hakkında bilgi seviyelerinin yetersiz olduğunu, eğitime ihtiyaç duyduklarını, kendileri, aileleri ve toplum için endişeli oldukları görülmüştür.

Ölçeklerin geçerliliklerinin sınanması maksadıyla yüzey geçerliliği, içerik-kapsam geçerliliği ve yapı geçerliliğine bakılmıştır (26). Yüzey geçerliliğine ilişkin araştırmacılar maddeleri uzunluk, okunurluk, anlaşılırlık bakımında gözden geçirmiştir. Pilot uygulamanın; örneklemin \%10'nu temsil eden sayıda deneğe uygulanması ve ardından alınan dönütler ile maddelerin yeniden değerlendirilmesi önerilir $(26,35)$. Çalışmamızda ölçek taslağın ön denemesi 30 hemşirelik öğrencisi üzerinde gerçekleştirilmiş olup öğrencilerden araştırmanın amacı, yönergenin yeterli düzeyde açıklayıcı olup olmadığı, ölçek maddelerinin anlaşılırlığı, işaretleme alanın kolay olup olmadığı konusunda görüşleri alınmıştır. Öğrenci dönütleri neticesinde anlaşılmayan sözler, terimler ve uzun cümleler sadeleştirilmiştir. Ardından kapsam geçerliliğini sağlamak için 8 uzmanın görüşüne sunulmuştur. İçerik geçerlik oranlarının belirlenmesinde Lawshe tekniği kullanılmıştır. Lawshe, tekniğine göre $\alpha=0.05$ anlamlılık düzeyinde KGO’ların minimum/kritik değerleri hesaplanmıştır, katılımcı olarak 8 uzman varsa İçerik Geçerlik Oranı (İGO) değeri 0.78'dir ve bu değerden küçük maddeler ölçekten çıkartılır $(25,37)$. İçerik geçerliliği oranları 0.78 'in altında olan 16 madde tutum ölçeğinden, 5 madde bilgi testinden çıkartılmıştır.

Son durumda 31 maddelik bilgi testi, 20 maddelik tutum ölçeği, 9 maddelik öz yeterlilik ölçeği üzerinden yapı geçerliliği analizleri aşamasına geçilmiştir. Yapı geçerliğinin sağlanmasında örneklem büyüklüğünün dikkate alınması gerekir (26). Çalışma 385 hemşire adaya sunulmuştur. Örneklem grubundan elde edilmiş olan verilerin, açımlayıcı faktör analizine uygunluğu Kaiser-Meyer-Olkin (KMO) ve Barlett Testi yapilarak ortaya konmaktadır. KMO değeri " 0 ile 1" arasında değişir. İyi bir faktör analizi için KMO ölçüsünün l'e yaklaşması ve 0.80 'den fazla olması istenir (36-37). Tutum ölçeği için yapılan $\mathrm{KMO}=0.893>0.60$; Barlett Testi $\mathrm{p}=0.000<0.05$ çımıştır; öz yeterlilik için yapılan analizler sonucunda $\mathrm{KMO}=0.910>0.60$, Barlett Testi $\mathrm{p}=0.000<0.05$ çımıştır. Bu bağlamda; çalışmamızın örneklem büyüklüğünün faktör analizi yapılması için yeterli olduğu ortaya konmuştur.

Faktör analizi yeni ortak kavramları ortaya çıkarma manasına gelir ve bunu faktör yük değerlerini kullanarak yapar. Faktör yükü en az 0.30 olmalıdır (38). Tutum ölçeği ve öz yeterlilik ölçeklerinin yapı geçerliliğini ortaya koymak maksadıyla açımlayıcı faktör analizi ve Varimax yöntemi seçilmiştir. İlk yapılan faktör analizi sonucuna göre faktör yük değerleri 0.30 değerinin altında olan 1., 2., 3. ve 12. maddeler tutum ölçeğinden çıkartılmıştır. Tekrarlanan analiz neticesinde; toplam açıllanan varyans \%66.401'dir ve yapı 3 faktör altında toplanmıștır. Öz 
yeterlilik için yapılan faktör analizi sonucunda toplam açıklanan varyans \%56.240’tır ve değişkenler tek faktör altında toplanmıştır. Bir ölçeğin varyans oranları ne derece yüksekse ölçeğin faktör yapısı da o kadar güçlü olur, tek faktörlü yapılar için en az \%30 ve üzerinde olmalıdır $(26,39)$. Bu bağlamda çalışmamız referans aldığı minumum \%50 varyans oranını karşılamaktadır.

KBRN tutum ölçeğinin iç tutarlılığını belirlemek için güvenirlik analizi yapılmıştır. Güvenirlik zamana göre değişmezlik ölçüsüdür yani ölçekte bulunan maddelerin birbirleri ve ölçek geneli ile tutarlı olup olmadığını ortaya koymaktadır. Ayrıca ölçekte yer alan ifadelerin katılımcılar tarafından aynı kapsamda anlaşılıp anlaşılmadığını belirler. Ölçeklerin güvenirliği Cronbach's Alpha katsayısı ile belirlenir (39). Tutum ölçeği Alpha katsayısı 0.925; Öz yeterlik Cronbach Alpha katsayısı 0.902 olarak bulunmuştur. Her iki ölçeğinde oldukça güvenilir olduğu yorumu yapılabilir.

Ölçümlerin güvenirliliğini zamana göre değişmezlik gösterebilme gücü önemlidir. Bu bağlamda bir testin aynı örneklem grubuna, aynı koşullarda fakat belli bir zaman aralığı verilerek ve işaretlenen formların eşlettirilmesiyle yapılan iki ölçüm arasındaki korelasyonun hesaplanması gerekir. Bu yönteme verilen isim test-tekrar test yöntemidir (39-44). Test-tekrar test yani diş tutarlılık değerlerini hesaplamak için Pearson korelasyon analizi yapılmıştır ve sonucunda ölçekler iki ölçüm arasında anlamlı farklilık göstermemektedir $(\mathrm{p}>0,05)$ Bu değerler ölçekte yer alan maddelerinin tamamının yüksek düzeyde bir dış tutarlığa sahip olduğunu kanıtlamaktadır. Ölçeklerden alınan İlk-son ölçüm puanları arasında benzerlik bulunmuştur. Bu bulgu ölçeklerin güvenilir olarak kullanılabileceğini söylemektedir.

Bilgi testi maddelerin niteliğini ortaya koymak için madde güçlük ve ayırt edicilik indeksleri analiz edilmiştir. Güçlük ve ayırt edicilik indeks değerleri; test için uygun olmayan maddeleri elemek, teste koyabileceğimiz maddeleri seçmek ve düzeltme gereken maddeleri bulmak amaçlarıyla yapılır (41). Madde ayırt edicilik indeksi, başarılı bir üst grup ile başarısız bir alt grubu birbirinden ayırt eder. Bu indeks değeri -1 ile +1 arasında derecelendirilir. İndeksin 0’a yakla- şıyor olması demek ayırt ediciliğin düşük olduğunu, l’e yaklaşıyor olması ayırt ediciliğin yüksek olduğunu anlatır ve ayrıca bu indeks maddelerin ölçülen özellikle ilgili bireyleri ne derece ayırt edebildiğini gösterir. Madde güçlük endeksi; bir maddenin doğru olarak cevaplandırılması oranıdır ve bu maddeyi doğru yanitlayanların sayısının sınava katılan toplam öğrenci sayısına bölünmesiyle hesaplanmaktadır. Madde güçlüğü 0.60'ın altında ise madde zor demektir $(9,46,47)$. $\mathrm{Bu}$ bağlamda $\mathrm{p}$ ve $\mathrm{r}$ değerleri incelenmiş olup aynı anda $\mathrm{p}<0.60, \mathrm{r}>0.20$ çıkan herhangi bir madde olmadığ 1 için bilgi testinden madde çıkartılmamıştır.

Bilgi testi güvenilirliğine yönelik bazı yaklaşımlar bulunmaktadır, en çok tercih edilen iç tutarlılık hesaplama yöntemi; Kuder-Richardson-20 (KR-20) indeksidir. KR-20 indeks değeri 0.0 ile 1.0 arasında değişen değerler alınmaktadır ve bu değer l'e yaklaştıkça tutarlı ölçüme kanıt olarak gösterilmektedir. KR-20 kısmen test uzunluğundan etkilenmekte ve test daha fazla öğe olduğunda daha yüksek olma eğilimindedir (48). Rudner ve Schafer'ye göre, öğretmen tarafından yapılan bir değerlendirmenin güvenirlik katsayılarını yaklaşık 0.50 veya 0.60 olarak göstermesi gerekmektedir (49). Salkind'a göre 50 maddeden daha uzun olan testler için 0.70 değeri kabul edilebilir bir değerdir (50). Bir matematik başarı testi için KR-20 değeri hesaplanır. Psikolojik bir test için; güvenirlilik katsayısının 0.70 ve üzerinde olması testten alınan puanların güvenirliği açısından yeterli görülmektedir(39). Çalışmamızda "Hemşirelik Öğrencisi KBRN Bilgi Testi” için KR-20 değeri; 0.82, Cronbach Alpha değeri; 0.82 olarak hesaplanmıştır.

\section{SONUÇ}

KBRN tutum ölçek puanı ve alt boyutlara ilişkin puanlar maddelere verilen puanların toplanarak madde sayısına bölünmesiyle elde edilmektedir. Ölçekten alınan puanlar 1 ile 5 arasında değişmektedir. 16 maddeden oluşmaktadır. Ölçekten alınan puanın yükselmesi KBRN tutum düzeyinin yükseldiğini göstermektedir. KBRN Öz yeterlilik puanı maddelere verilen puanların toplanarak madde sayısına bölünmesiyle elde edilmektedir. Öz yeterlilik ölçeği ise 9 maddeden 
oluşmaktadır. Ölçekten alınan puanın yükselmesi KBRN Öz yeterlilik düzeyinin yükseldiğini göstermektedir. Bilgi testi 2 seçenekli (doğru/yanlış) yapıda olup, 31 maddeden oluşmaktadır. Katılımcının aldığı puan arttıkça bilgi seviyesi de yükselmektedir.

$\mathrm{Bu}$ ölçekler tanımlayıcı çalışmalar ve girişimsel çalışmalar için veri toplama aracı olarak bir bütün halinde veya çalışmanın amacına göre ayrı ayrı kullanılabilir. Yapılacak çalışmalar sayesinde hemşirelik bilgi üretimine katkı sunacağı düşünülmektedir.

Hakem Değerlendirmesi: Dış bağımsız.

Peer Review: Externally peer-reviewed.

Etik Komite Onayı: Bu çalışma için etik komite onayı Bursa Uludağ Üniversitesi Araştırma ve Yayın Etik Kurulları-Sağlık Bilimleri Araştırma ve Yayın Etik Kurulu'ndan alınmıştır. (27.03.2019/ No:10)

Ethics Committee Approval: Ethics committee approval for this study was received from Bursa Uludağ University Research and Publication Ethics Committees-Health Sciences Research and Publication Ethics Committee. (27.03.2019 / No: 10)

Bilgilendirilmiş Onam: Katılımcılardan bilgilendirilmiş onam alınmıştır.

Informed Consent: Written consent was obtained from the participants.

Yazar Katkıları: Çalışma Konsepti/TasarımD.A.H., M.N.E.; Veri Analizi/Yorumlama- D.A.H.; Yazı Taslağ1- D.A.H.; İçeriğin Eleştirel İncelemesiD.A.H., M.N.E.; Son Onay ve Sorumluluk- D.A.H., M.N.E.

Author Contributions: Conception/Design of Study- D.A.H., M.N.E.; Data Analysis/InterpretationD.A.H.; Drafting Manuscript- D.A.H.; Critical Revision of Manuscript- D.A.H., M.N.E.; Final Approval and Accountability- D.A.H., M.N.E.

Çıkar Çatışması: Yazarlar çıkar çatışması beyan etmemişlerdir

Conflict of Interest: Authors declared no conflict of interest.

Finansal Destek: Yazarlar finansal destek beyan etmemişlerdir.

Financial Disclosure: Authors declared no financial support.

\section{KAYNAKLAR}

1. Afet ve Acil Durum Yönetimi Başkanlığı. (2019). KBRN Sözlügü. https://www.afad.gov.tr/kbrnsozlugu. (Alıntılama tarihi 10 Mart 2019).

2. Centre for the Protection of National Infastructure. Chemical, Biological, Radiological and Nuclear (CBRN) Threats. https://www.cpni.gov.uk/ chemical-biological-radiological-and-nuclearcbrn-threats-0 (Alıntılama tarihi 10 Mart 2019).

3. Veenema TG. Chemical and biological terrorism preparedness for staff development specialists. J Nurses Staff Dev 2003;19(5):215-22.

4. Coica R, Kachur E, Lima V, Lipper S. Guidelines for preclerkship bioterrorism curricula. Acad Med 2004;79(4):366-75.

5. Joint Commission on Accreditation of Healthcare Organizations. Standing Together An Emergency Planning Guide for America's Communities, 2005:s.35. Available from: https://www.jointcommission.org/-/media/ deprecatedunorganized/imported assets/ tjc/systemfolders/ topics-library/planning guidepdf.pdf (Alıntılama tarihi 12 Mart 2019).

6. Nash TJ. A guide to emergency preparedness and disaster nursing education resources. Heal Emerg Disaster Nurs 2017;4:12-25.

7. Hick JL, Hanfling D, Burstein JL, Markham J, Macintyre AG, Barbera JA. Protective equipment for health care facility decontamination personnel: regulations, risks, and recommendations. Ann Emerg Med 2003; (3):370-80.

8. Çıtlık Sarıtaş S, Kızıl BA, Sarıtaş S. Acil servis hemşirelerinin biyoterörizm konusundaki bilgi ve görüşleri. Bozok Tip Derg 2013;2:29-36.

9. Büyüköztürk Ş, Kılıç Çakmak E, Akgün ÖE, Karadeniz Ş, Demirel F. Bilimsel Araştırma Yöntemleri. Ankara: Pegem Akademi Yayınevi; 2011.s. 1-340.

10. Afet ve Acil Durum Başkanlığı. Kimyasal Biyolojik Radyoloji Nükleer Tehditler. 2019. Available from: https://www.afad.gov.tr/kbrn (Alıntılama tarihi 12.03.2019) .

11. Sanström BE, Eriksson H, Norlander L, Thorstensson M, Cassel G. Training of 
public health personnel in handling CBRN emergencies: A table-tip exercise card concept. Environ Int 2014;72:164-9.

12. Kako M, Hammad K, Mitani S, Arbon P. Existing approaches to chemical, biological, radiological, and nuclear (CBRN) education and training for health professionals: Findings from an integrative literature review. Prehosp Disaster Med 2018;33(2):184-90.

13. Ayvazoğlu G. KBRN için hazırlılık ve gönüllülük düzeyi belirleme çalışması: Gümüşhane ili örneği. Gümüsshane Üniversitesi: Sosyal Bilimler Enstitüsü, Yüksek Lisans Tezi. Gümüşhane, 2015.ss.54-89.

14. Türkiye Cumhuriyeti Sağlık Bakanlığı. Hastane Afet ve Acil Durum Planı (HAP) Hazırlama Kilavuzu. 2017. Available from: https://dosyasb. saglik.gov.tr/Eklenti/854, hap-kilavuzpdf.pdf (Alıntılama tarihi 12.03.2019).

15. Uludağ N. Şile-Kandıra-İzmit bölgelerindeki kaynak sularında radon gazının incelenmesi ve sakarya üniversitesi radon farkındalık anketi. Sakarya Üniversitesi: Fen Bilimleri Enstitüsü, Yüksek Lisans Tezi. Sakarya, 2018:ss.54-64.

16. Milli Eğitim Bakanlığı. Kimyasal Biyolojik Radyasyon ve Nükleer (KBRN) Tehlikelerde Acil Yardım. 2011. Available from: http://megep. meb.gov.tr/mte_program_modul/moduller_pdf (Alıntılama tarihi 12.03.2019).

17. Sezigen S, Ortatatlı M, Eyison K, Demirkasımoğlu M. Kimyasal savaş yaralılarının tıbbi yönetimi için pratik rehber.kimyasal silahların yasaklanması örgütü uluslararası işbirliği ve yardım bölümü destek ve korunma kısmı. Çeviri editörü, L Kenar, S Sezigen. Ankara: Sağlık Bilimleri Üniveristesi Tibbi KBRN AD. Başkanlığı, Ankara İl Sağlık Müdürlüğ̈̈;2016:s.1-156.

18. Young CF, Persell DJ. Biological, chemical, and nuclear terrorism readiness: major concerns and preparedness of future nurses. Disaster Manag Response 2004;2(4):109-13.

19. Stokes E, Deborah GP, Skorga P, Young C, Deborah P. Chemical agents of terrorism: preparing nurse practitioners. Nurse Pract 2004;29(5):30-9.
20. Rebmann T, Mohr LB. Bioterrorism knowledge and educational participation of nurses in missouri. J Contin Educ Nurs 2010;41(2):67-76.

21. Nyamathi A, Casillas A, King ML, Gresham L, Pierce E, Farb D, Weichman C. Computerized bioterrorism education and training for nurses on bioterrorism attack agents. J Contin Educ Nurs 2010;41(8):375-84.

22. Mitchell CJ, Kernohan GW, Higginson R. Are emergency care nurses prepared for chemical, biological, radiological, nuclear or explosive incidents? International Emerg Nurs 2012;20:151-61.

23. Aghaei N, Nesami MB. Bioterrorism education effect on knowledge and attitudes of nurses. J Emerg Trauma Shock 2013;6(21):78-82.

24. Gorji HA, Niknam N, Aghaei N, Yaghoubi T. An assesment of knowledge and attitude of iranian nurses towards bioterrorism. Iran Red Crescent Med J. 2017;19(11):1-5.

25. Lawshe $\mathrm{CH}$. A quantitative approach to content validity. Pers Psychol 1975; 28(4):563-75.

26. Şencan H. Sosyal ve Davranissal Ölçümlerde Güvenilirlik ve Geçerlilik. Ankara: Seçkin, 2005:s.51-410.

27. Turgut MF. Eğitimde Ölçme ve Değerlendirme Metodları. Anakara: Yargıc1 Matbaası; 1995:s.13-48.

28. Kızılkaya M. Çanakkale onsekiz mart üniversitesi acil yardım ve afet yönetimi bölümü öğrencilerinin kbrn olaylarına karşı hazırlık algıları ve bilgi düzeylerinin belirlenmesi. Çanakkale Onsekiz Mart Üniversitesi: Eğitim Bilimleri Enstitüsü, Yüksek Lisans Tezi. Çanakkale,2020:s.65-74.

29. Kaynak C. Örnek bir hastane afet ekibinin doğal afetler sonrasında ortaya çıkabilecek KBRN (kimyasal, biyolojik, radyoaktif, nükleer) tehlikeler ile ilgili bilgi düzeylerinin ölçülmesi. Çanakkale Onsekiz Mart Üniversitesi: Fen Bilimleri Enstitüsü, Yüksek Lisans Tezi. Çanakkale, 2020:s.21-36.

30. Yildırım T. KBRN ekiplerinin olay müdahale yöntemlerinin incelenmesi: Adana AFAD örneği. T.C. Bitlis Eren Üniversitesi: Fen 
Bilimleri Enstitüsü, Yüksek Lisans Tezi. Bitlis, 2019:s.54-56.

31. Doğan G. KBRN olaylarına karşı kurumların bilgi, eğitim ve tatbikat ihtiyaçlarını belirleme çalışması: gümüşhane ve trabzon illeri örneği. Gümüşhane Üniversitesi: Sosyal Bilimler Enstitüsü, Yüksek Lisans Tezi.Gümüşhane: 2019. s.97-124.

32. Dönmez AM. Acil tıp çalışanlarının (KBRN) kimyasal, biyolojik, radyolojik, nükleer kazalara karşı ilgi, bilgi ve tutum durumu araştırması. Bezm-i Alem Vakıf Üniversitesi: Sağlık Bilimleri Enstitüsü, Doktora Tezi. İstanbul, 2019:s. 57-80.

33. Akbal KY. Hastane çalışanlarının kimyasal, biyolojik, radyoaktif, nükleer vakalarına karşı bilgi ve davranış düzeyinin incelenmesi. Üsküdar Üniversitesi: Sağlık Bilimleri Enstitüsü,Yüksek Lisans Tezi. İstanbul,2019:s.66-97.

34. Andsoy I, Kes D, Top R, Dikici İC. Dünyanın tehdidi kimyasal savaş: hemşireler kimyasal bir saldırı durumunda yapılması gereken uygulamalara ilişkin neler biliyor? Bozok Tip Derg 2016;6(3):15-20.35.

35. Dost A, Bahçecik N. Hemşirelik mesleğine yönelik imaj ölçeği geliştirilmesi. JAREN 2015;1(2):51-9.

36. AndersonJC.EducationalResearchMethodology and Measurement. An International Handbook. Keeves J. editör. New York: Pergamon press, 1988. 340-44. p.

37. Ayre C, Scally AJ. Critical values for lawshe's content validity ratio. Methods Plainly Speak 2013;47(1):79-86.

38. Çokluk ÖS, Şekercioğlu G, Büyüköztürk S. Sosyal Bilimler için Çok Değişkenli İstatistik: Spss ve Lisrel Uygulamaları. Ankara: Pegem Akademi Yayıncilık, 2012:s.177-246.

39. Büyüköztürk Ş. Veri Analizi El Kitabı. 22.Baskı. Ankara: Pegem Akademi Yayınevi; 2016:s.179-194.
40. Karagöz Y, Kösterelioğlu İ. İletişim becerileri değerlendirme ölçeğinin faktör analizi metodu ile geliştirilmesi. Dumlupınar Üniversitesi Sosyal Bilimler Dergisi,. 2008;21:81-98.

41. Şekercioğlu G, Bökeoğlu ÖÇ, Büyüközürtk Ş. Öğretmen adaylarında araştırma özyeterliliğinin farklı değişkenler açısından incelenmesi ve yordayıcılarının belirlenmesi. Akdeniz Univ Egi Fak Derg 2018;1(2):137-47.

42. Costello AB, Osborne JW. Best practices in exploratory factor analysis: Four recommendations for getting the most from your analysis. Practical Assessment 2005;10(7):1-9.

43. Yong AG, Pearce SA. Beginner's guide to factor analysis: focusing on exploratory factor analysis. Tutor Quant Methods Psychol 2013;9(2):79-94.

44. Erdoğan S, Nahcivan N, Esin MN. Hemşirelikte Araştırma: Süreç, Ugulama ve Kritik. 1st ed. Nobel Tip Kitabevleri, 2015:s.218.

45. Turgut MF, Baykul Y. Eğitimde Ölçme ve Değerlendirme. Ankara: Pegem Akademi, 2012:s.315.

46. Bayrakçeken S. Test Geliştirme, Ölçme ve Değerlendirme. 5.baskı. Karip E. (editör). Ankara: Pegem Akademi Yayınevi, 2012. p.294-324.

47. Gündüz Sefer D, Karabay Koçyiğit B. Klasik sınavların bilgisayarda değerlendirilmesine ilişkin bir uygulama. XIII Ulusal Eğitim Bilimleri Kurultayı. İnönü Üniversitesi Eğitim Fakültesi, 2004; Malatya,Türkiye.

48. Kehoe J. Basic 1tem analysis for multiple-choice tests. A Peer-Reviewed Electron J. 1995;4(10):1-5.

49. Rudner LM, Schafer WD. What Teachers Need to Know About Assessment. Washington: National Education Association, 2002:s.56-91.

50. Salkind NJ. Encyclopedia of Research Design. SAGE Publications, 2010. p.667. 